\title{
Morphological changes in periodontal tissues under the influence of magnetophototherapy
}

\author{
S.P. Rubnikovich ${ }^{1}$, A.I. Maizet ${ }^{2}$, Yu.L. Denisova ${ }^{3}$ \\ ${ }^{1} \mathrm{MD}, \mathrm{PhD}, \mathrm{DMSci}$, Professor, Belarusian Medical Academy of Postgraduate Education, Minsk, Belarus \\ ${ }^{2}$ Belarusian Medical Academy of Postgraduate Education, Minsk, Belarus \\ ${ }^{3} \mathrm{MD}, \mathrm{PhD}, \mathrm{DMSci}$, Professor, Belarusian State Medical University, Minsk, Belarus
}

\begin{abstract}
Summary. The effect of a low-intensity magnetic field combined with polarized light on the microvasculature links in periodontal tissues during orthopaedic treatment by fixed dentures in patients with partial secondary adentia and periodontal diseases were determined using an experiment on laboratory animals.

The aim of the research was to study the character of morphological changes in the tissues of pathologically changed periodontium after exposure to magneto phototherapy in animal testing.

Objects and methods. The experiment was made on selected 107 random-bred rats. The animals were divided into three groups: control group 1 , control group 2 , and the experimental group.

Results and discussion. A dynamic analysis of morphological changes in the tissues of pathologically changed periodontium in three groups of animals demonstrated that, as compared to other animals, the rats from the experimental groups, following experimental magneto phototherapy, had early elimination of inflammation.

Conclusion. Early elimination of inflammation (1 hour after termination of the impact) in all gum components and perifocal structures due to vaporization of inflammatory cells, activation of vessels (plethora and a noticeable increase in number) was found after the exposure to magneto phototherapy, while regeneration and complete epithelialization of the gingival pocket completed 2 days after termination of magneto phototherapy.
\end{abstract}

Keywords: partial secondary adentia, periodontal diseases, magneto phototherapy, animal studies

\section{Морфологические изменения тканей периодонта при магнитофототерапии}

\author{
С.П. Рубникович ${ }^{1}$, А.И. Майзет ${ }^{2}$ Ю. А. Аенисова ${ }^{3}$ \\ ${ }^{1}$ А-р меА. наук, профессор, Белорусская медицинская академия последипломного образования, Минск, Беларусь \\ ${ }^{2}$ Белорусская медицинская академия последипломного образования, Минск, Беларусь \\ ${ }^{3} \mathrm{~A}$-р меА. наук, профессор, Белорусский государственный меАицинский университет, Минск, Беларусь
}

Резюме. Цель исследования. Изучить характер морфологических изменений в тканях патологически измененного периодонта под вмиянием магнитофототерапии в эксперименте на животных.

Материал и методы. 107 рандомбредных крыс обоего пола, которых разАелими на 3 группы. В контрольной группе определяки состояние зАоровой Аесны, в группе сравнения инициировали экспериментальный периодонтит, не применяли магнитофототерапию, в опытной группе животным с экспериментальным периодонтитом проводими магнитофототерапию. Во всех группах определяли патоморфологические изменения в тканях периодонта.

Результаты исследования и их обсуждение. НепосреАственно после возАействия у экспериментальных животных прослеживали коагуляции и вапоризацию воспалительного экссудата Аесневой борозАы и клеток воспаления собственной пластинки Аесны. Через 1 час после возАействия наблюАали полную элиминацию воспалительного экссудата Аесневого кармана и клеток воспаления собственной пластинки десны или предкоагуляционные изменения сохранившихся. Через 2 часа - начинающаяся регенерация десневого кармана. Через 3 часа - восстановление клеточной структуры эпителия Аесны, частичная эпителизация Аесневого кармана, более выраженная через сутки и почти полную через 2 суток.

Заключение. После воздействия магнитофототерапии установлена ранняя элиминация воспаления (через 1 час после прекращения возАействия) во всех компонентах десны и перифокальных структурах за счет вапоризации воспалительных кметок, активация сосудов. Регенерация и полная эпителизация Аесневого кармана были завершены через 2-е суток после прекращения возАействия магнитофототерапии, что свидетельствует о высокой эффективности ее применения.

Ключевые слова: частичная вторичная адентия, болезни периодонта, магнитобототерапия, рагtial, эксперимент на животных 
A ccording to the epidemiological surveillance of the Republic of Belarus, the prevalence of periodontal diseases remains high, making $92.5 \pm 1.27 \%$ (100\% in 1996). The efficacy of comprehensive treatment of patients with periodontal diseases depends on the use of additional treatment and prevention interventions $[1-3,7]$.

Application of physical factors for comprehensive treatment of inflammatory diseases is an important part of comprehensive treatment. The use of physical factors at different stages of a disease makes it possible not only to eliminate the initial signs of the pathological process, but also to reduce the intensity of its clinical manifestation and the probability of relapse, thereby giving the most optimal treatment outcomes.

Combined or supplementing physiotherapeutic treatment of periodontal diseases provides a number of advantages: potentiated action of several factors has a more obvious therapeutic effect; reducing the intensity and duration of the procedures and of the course of treatment; and mutual action of the physical factors at the biological, physical and physico-chemical stages of their effect [4-6].

Numerous contemporary domestic and foreign studies prove that the use of low-intensity magnetic field combined with polarized light of different wavelengths (blue, red and infrared spectral regions) have high clinical efficacy. Magneto phototherapy causes analgesic and hypotensive effects, as well as pronounced antiedemic and anti-inflammatory action in the tissues. The action and efficacy of magneto phototherapy are defined by physiological and $\mathrm{cu}-$ rative effects of combined physical factors, i.e., light and magnetic field, on one hand, and by the interaction of these factors and the shifts induced in the body, on the other hand.

The use of magneto phototherapy at different stages of dental treatment stimulates biosynthetic processes and generation of phosphates rich in energy, enhances regional circulation and microcirculation, stimulates erythropoiesis, decreases aggregation of blood platelets, enhances oxygen capacity of blood, etc. Combined use of magnetic field and phototherapy causes magneto photoelectric effect (Kikoin-Noskov effect), inducing a powerful electromotive force in the tissues. Magnetic fields facilitate deep penetration of optical radiation into the tissues and increase the range of optical radiation perception by the cells. Magnetic fields cause the splitting of energy levels and spectral lines of atomic systems in the tissues, thereby imparting them additional energy (Zeeman effect). Combined effect of light and magnetic field enhances each of the factors and increases the total therapeutic activity of the method $[8,9]$.

\section{THE AIM OF THE RESEARCH}

The goal of the research was to study the character of morphological changes in the tissues of pathologically changed periodontium after exposure to magneto phototherapy in animal testing.

\section{- OBJECTS AND METHODS}

In order to reach this goal, the experiment included 107 random-bred rats of both sexes, 209-243 g of body weight, divided into 3 groups.

Before the experiment, the animals were in quarantine for two weeks in the vivarium of the BelMAPO research laboratory (Belarusian Medical Academy of Post-Graduate Education). The experiment was made on selected apparently healthy and active animals with smooth and glossy hair coat, normal physiological colour of the mucous membranes, with normal appetite. Additional examinations and weighing of animals were made on the day of experimentation. The experimental animals were divided into the observation groups based on their body weight and sex.

All animals were kept in absolutely identical conditions: they were given regular diet in the vivarium for 45 - 52 days. It was proven that after "suppression of the freedom reflex" the rats, kept on a regular diet in the vivarium, developed periodontitis (spontaneous periodontitis) that can be used as a model for a similar disease in humans [15-23].

During the experiment, all testing was made in conformity with the rules for experimental animals fully complying with all principles of bioethics for anesthetized animals [24, 25]. General anaesthesia was made using a mixture of $1 \mathrm{ml}$ of $0.005 \%$ fentanyl solution and $2 \mathrm{ml}$ of $0.5 \%$ droperidol solution. Following anaesthesia, the animals were fixed on their back in special equipment for rapid standardized manipulations.

Control group 1 (5 random-bred rats) was used to study periodontal tissues in order to define the condition of the healthy gum, followed by pathomorphological evaluation of the healthy gum biopsy material.

Control group 2 (42 random-bred rats) included laboratory animals with experimentally induced periodontitis, for which no magneto phototherapy was used, followed by pathomorphological evaluation of the biopsy material. 
The exponential group (60 random-bred rats) included laboratory animals with experimental periodontitis, for which magneto phototherapy was applied, followed by pathomorphological evaluation of the biopsy material directly after physical impacts, after 1 hour, 2 hours, 3 hours, as well as every day from day 1 to day 8 after treatment. Also, the character of pathomorphological changes in the tissues of pathologically changed periodontium after magneto phototherapy was determined.)

Physical impact was exerted on the gum area, the mandibular central incisors of animals with periodontitis. Magneto phototherapy was performed using a device for magneto phototherapy with magnetic field induction from 15 to $25 \mathrm{MT}$, the radiation wavelength from 460 to $960 \mathrm{~nm}$, and the radiation flow power from 1.5 to $4.5 \mathrm{~mW}$.

The experiment was terminated, upon completion of the period of animals observation (the experimental group and control group 2), by instant decapitation after intraperitoneal thiopental narcosis administered as $1 \mathrm{ml}$ of $5 \%$ thiopental sodium per 100 grams of the body weight, abiding by the principles of bioethics (according to GLP). The material for microscopy studies was taken immediately after magneto phototherapy, and after 1,2 and 3 hours, as well as each day from day 1 to day 8 after treatment.

For morphological studies, a mucoperiosteal flap (14-15 $\left.\mathrm{mm}^{2}\right)$ of the lower gum process was obtained; then the dissected gum area of the rat was fixed in a 10\% neutral formalin for 48 hours, washed in running water for 24 hours, and dewatered in alcohols of increasing concentrations (70\%, 80\%, 96\%, and absolute alcohol). Then the material was treated by alcohol-chloroform, chloroform, chloroform-paraffin, and placed to paraffin. The paraffin blocks were used to cut sections 4-5 $\mu \mathrm{m}$ thick, stained with haematoxylin and eosin. The obtained micro preparations were tested, and their micro photos were produced by a DMLS microspore with software (Leica, Germany).

\section{RESULTS AND DISCUSSION}

The control group. The morphological studies demonstrated that the condition of periodontal tissues was within the norm during the experimental observation periods. The microscopic structure of the hum was identical in all rats studied in this group.

Keratinized stratified squamous epithelium (KSSE) of the gingival crevice and the free part of the gum is, basically, uniformly thin, with thickened spots, mostly in the free part of the gum, and stratified. The basal layer was represented by 1-2 rows of low cubic or elongated cells, sometimes with vesicular cytoplasm, in a row of stakes in some places. The epithelial ridges were predominantly wide and low, some of them thin and elongated, which forms the relevant microstructure (papillary layer) of the gum lamina propria (LP). The spinous layer cells were arranged in 1-3 rows, in some places they were eliminated and in these areas the granular layer cells are adjacent to the basal layer. The granular layers were mostly elongated and contained dust granules of keratohyalin; the nuclear of such cells looked as "shadows" or could not be visualized on the boundary with a cornified layer. This layer had some thickened spots, such as - hypertrophy of granular layers, cytoplasmic vesiculation, nuclear fragmentation, and, predominantly, accumulation of keratohyalin lumps. The cornified layer was uniformly thin, clearly seen in the free part of the gum. Hyperkeratosis areas were observed. The epithelium of the attached alveolar gum was stratified, squamous and non-stratified, and fixed to the periodontal ligament and the periosteum of alveolar process of the jaw bone.

The gingival crevice was narrow and short. The gum LP represented non-structured connective tissue (CT), loose in the papillary layer, and a loosely delimitated net-like layer of the non-structured $\mathrm{CT}$ and bulky collagen fibres (CFs). CT of both layers had a few cells; the cells mostly manifested fibroblasts and fibrocytes, as well as individual lymphocytes, histiocytes, plasma cells and eosinophilic mononuclear cells. Rare arterial capillaries, small groups or individual, arterioles without blood components in the lumen, as well as rare plethoric venous capillaries and venules, and optically empty lymphatic capillaries were identified inside the LP (Fig. 1).

Control group 2. Immediately after termination of the stress impact: suppurative inflammation and destruction of the area where the gum attached to the separated part and the gingival crevice bottom, elongation and expansion of the latter with formation of the gingival pocket, and the presence of puss in its pocket. Inflammation spreads to the periodontal ligament with microabscess, and the gum LP, most intensive in the perifocal sections of the latter, where purulent blood clots are found in the capillaries. Inflammatory infiltration of the epithelium basal layer of the free part of the gum in the apical area, dystrophy and inflammatory infiltration of 


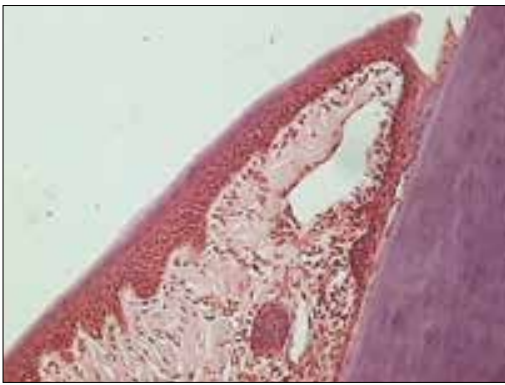

Fig. 1. Location of arterial, venous and lymphatic capillaries, arterioles and venules in the gum LP of animals from the control group. Stained with haematoxylin and eosin. Magnification factor 200X

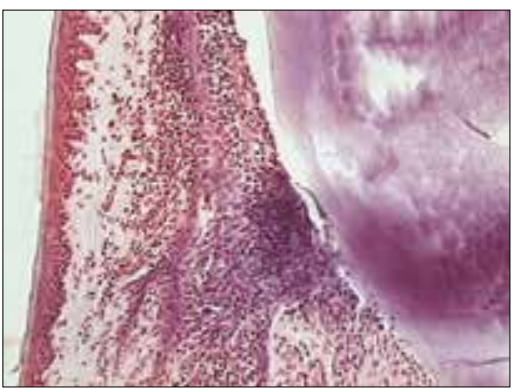

Fig. 4. Morphological changes of periodontium tissues in the experimental animals 1 day after termination of the stress effect. Purulent proliferative inflammation, inflammation spreading to the gum LP, periosteum of alveolar process of the jaw bone and the periodontal ligament. Stained with haematoxylin and eosin. Magnification factor 200X
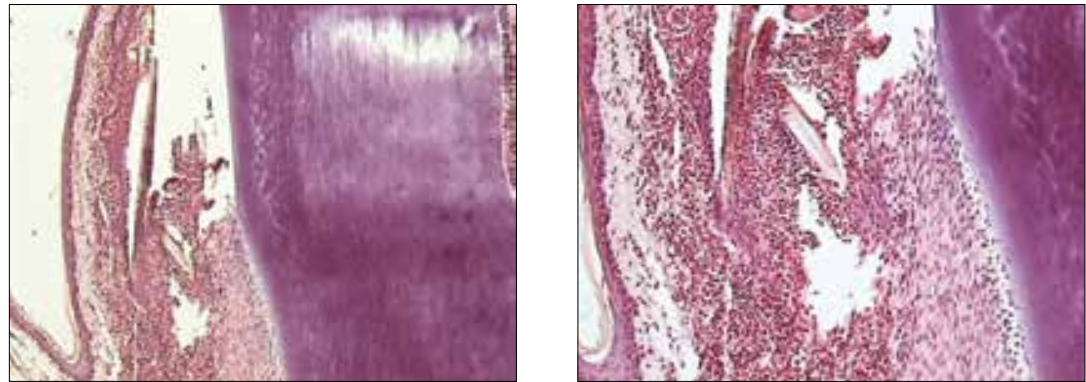

Figs. 2, 3. The morphological changes of periodontium tissues in experimental animals directly after termination of the stress effect. KSSE of the external surface of the free part of the gum was not changed, actually. Stained with haematoxylin and eosin. Magnification factor 100-200X
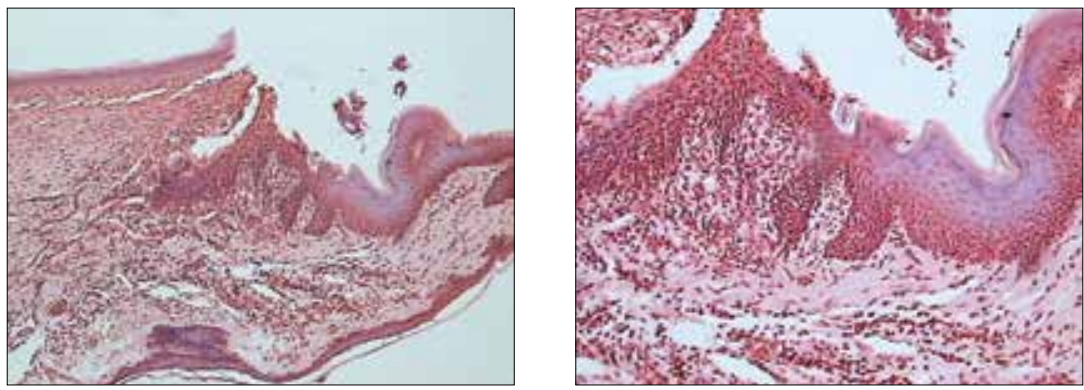

Figs. 5, 6. The morphological changes of periodontium tissues in experimental animals 2 days after termination of the stress impact. Small proliferative inflammation spots in the gum LP. Stained with haematoxylin and eosin. Magnification factor 100-200X epithelium of the proximal part of the gingival crevice were observed. KSSE of the external surface of the free part of the gum was not changed, mostly (Figs. 2, 3).

One day (subgroup I) after termination of the stress impact, the microscopic changes of the gum were similar in all studied rats. In the mucoperiosteal flap of the animals, changes in the gingival crevice epithelium (uneven thickness with segmental elimination of the layers, dystrophy and cytolysis of the basal cells, few elongated cells of the granular layer with single dust granules, transformation of its cells to keratinocytes and formation of the cornified layer) were observed. Intensive purulent proliferative inflammation with destruction and separation of the junctional epithelium was found and, as a consequence, noticeable deepening of the gingival crevice and formation of the gingival pocket, periosteal microabscess, puss accumulation and purulent detritus in the deepened and expanded gingival crevice, inflammation spreading to the gum LP, the periosteum of alveolar process of the jaw bone, and the periodontal ligament (Fig. 4).

It was observed that the LP of the free segment of the gum included small spots of proliferative inflammation, abundant slit-like lymph capillaries (optically empty), non-functioning few blood capillaries (without blood components in the lumen), with thickened walls and dystrophy of endotheliocytes. The gingival epithelium had smoothed papilla of the basal layer.

On day 2 (subgroup II), the morphological indicators matched the same indicators of subgroup I (Figs. 5, 6).

On day 3 (subgroup III), the microscopic changes of the differed slightly from the microstructure of the gum in rats from subgroup I. Slightly reduced intensity of the purulent inflammation in the gingival pocket, the periosteum of alveolar process of the jaw bone, as well as proliferative inflammation of the gum LP, as well as focal accumulated dilated plethoric 


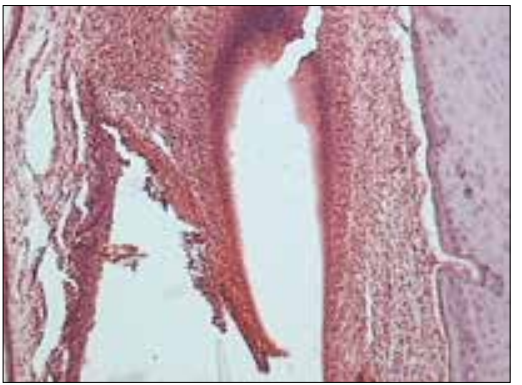

Fig. 7. The morphological changes of periodontium tissues in experimental animals 3 days after termination of the stress effect. Slightly reduced intensity of the suppurative inflammation of the gingival pocket, and the periosteum of alveolar process of the jaw bone. Stained with haematoxylin and eosin. Magnification factor $100 \mathrm{X}$

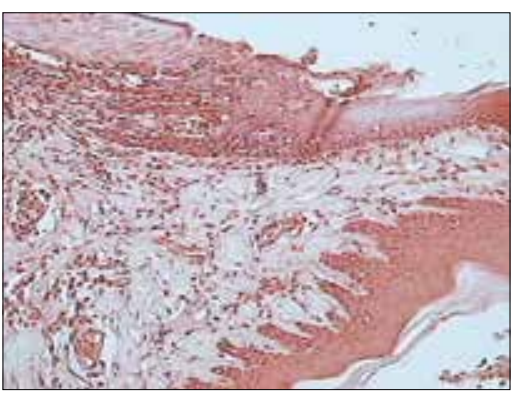

Fig. 10. The morphological changes of periodontium tissues in experimental animals 5 days after termination of the stress effect. Slightly expressed seropurulent inflammation of the gum LP. Stained with haematoxylin and eosin. Magnification factor 200X
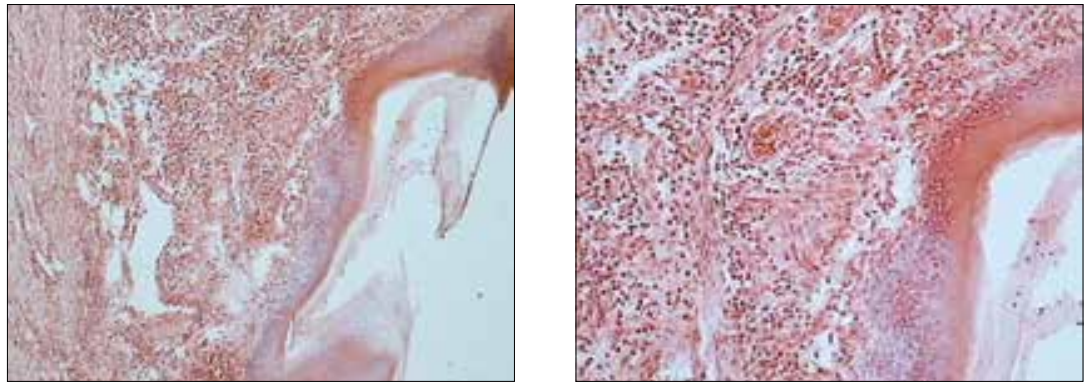

Figs. 8, 9. The morphological changes of periodontium tissues in experimental animals 4 days after termination of the stress impact. Seropurulent inflammation of the gum LP, the periodontal ligament and the periosteum. Stained with haematoxylin and eosin. Magnification factor $100-200 X$
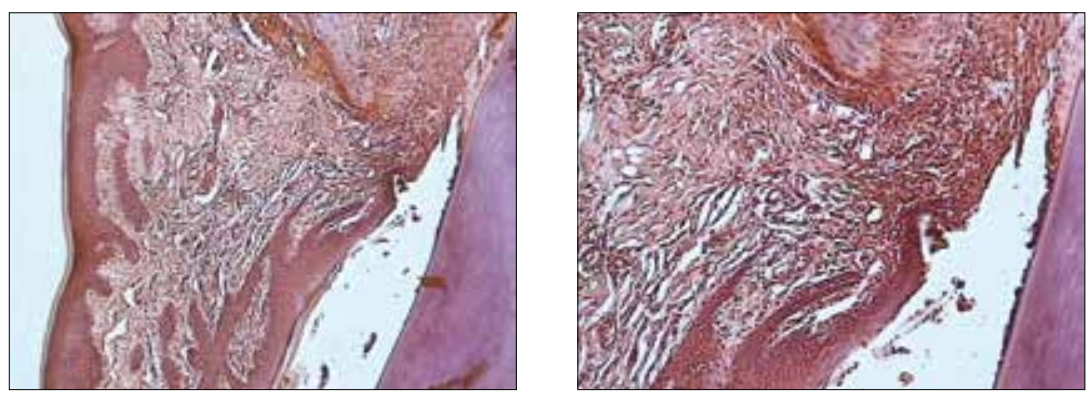

Figs. 11, 12. The morphological changes of periodontium tissues in experimental animals 8 days after termination of the stress effect. Cytolysis of the epithelial cells with spotted growth of maturing granulation tissue and signs of serous inflammation. Stained with haematoxylin and eosin. Magnification factor 100-200X capillaries and venules up to 5-6 in the field of microscope were observed (Fig. 7).

On day 4 (subgroup $I V$ ) after termination of exposure, a broad and deep gingival crevice and the gingival pocket were present. Epithelial ridges elongated in the proximal part of the gingival crevice, and the surface erosion in the distal part of epithelium, filled with necrotic detritus and purulent effluent, were observed. Destruction of the junctional epithelium external layers with diffused seropurulent inflammation, papillomatosis of the deep epithelial layer in this part of the gum and the formation of perifocal nodular structures from mature granulation tissue, i.e., abnormal regeneration and epithelialization were observed (Fig. 8). In the experimental animals, moderately expressed seropurulent inflammation of the gum LP, the periodontal ligament and the periosteum, expressed reactive changes of the latter with formation of bulky nodular fibromatous structures; and weak spotted activation (of inflammation origin) of the functioning vessels (few plethoric capillaries, i.e., 3-5 in the field of microscope) were identified (Fig. 9).

On day 5 (subgroup $V$ ), a deep and broad gingival crevice, and destruction of the junctional epithelium were observed. Disseminated moderate seropurulent inflammation and seropurulent inflammation slightly expressed in some places (mostly the latter) of the gum LP, the periodontal ligament and the periosteum of alveolar process of the jaw bone, as well as intensive fibroblast hyperplasia were observed (Fig. 10).

In the periodontal pocket bottom area, small spots of proliferation of stratified squamous epithelium (SSE) grown into the periodontal ligament and the periosteum (abnormal regeneration), as well as spots of increasing functional (plethoric) capillaries up to $15-17$ in the field of microscope with 200X (focal spots of granulation tissue) were identified. Cellular dissociation of SSE in the free part of the gum, i.e., enhanced keratosis and formation of small 
parakeratotic papules, elongation and expansion of epithelial ridges with growth, was also observed.

On day 8 (subgroup VIII), a deep gingival crevice with inhomogeneous gingival epithelium, mostly thin with segmental destruction of the surface layers, was observed. In its middle and end, an expressed elongation of epithelial ridges was observed, with disorientation and growth into the gum LP. In the distal part, the beginning focal regeneration of epithelium with disordered arrangement of cells, cytolysis of the epithelial cells at the crevice bottom with exposure of the gum LP (ulceration), and a focal growth of the maturing granulation tissue in this area with signs of serous inflammation were visualized (Figs. 11, 12).

Relatively bulky spots of a similar granulation tissue inside the periodontal ligament were identified with sharply expressed hyperplasia of the cell component of the latter. In the apical segment of the free part of the gum, SSE dystrophy and surface erosion with a small spot of lymphocytes and signs of epithelialization were identified. Slight oedema of the gum LP, focal dilated and merging optically-empty thin-wall lymphatic vessels, diffusely scattered cells compressed minor and plethoric capillaries with few blood components (up to 10-15 in the field of microscope with 200X), small spots of perivascular lymphocyte penetration, and pockets of ectatic and plethoric venules in the gingival crevice bottom were visualized (Fig. 13).

The experimental group. Microscopic structure of the gum in all tested rats were identical within each subgroup.

Immediately after termination of magneto phototherapy (subgroup I -E (experimental)), partial separation of the cornified and glittering layers was observed. Vacuolization (vaporization) of diffusely scattered cells of the granular and spinous layers and pre-coagulation changes of the stratified squamous epithelium in the free edge and the attached part of the gum were seen. Coagulation changes (compaction, homogenisation) and vaporization of inflammatory cells of the gingival pocket; loosening (vaporization) of college fibres of the gum LP, subtotal vaporization of inflammatory cells, with few destroyed cells remaining, basically, perifocal of the gingival pocket were visualized (Figs. 14, 15).

One hour after magneto phototherapy (subgroup $I I-E)$, SSE cornified layer was not visualized (pre-coagulation changes), glittering and uniformly thin. Singular vacuolar (vaporization) cells were found in the spinous layer, and pre-coagulation changes of SSE cells remained. Total elimination of inflammatory lymph from the gingival pocket and formation of dense fibrous tissue on the edge of the gum SSE defect in the distal part and the gingival pocket bottom was present. Disseminated vaporization of inflammatory cells of the gum LP was seen, with destroyed (coagulation and pre-coagulation changes) in a small area perifocal of the bottom and the inner edge of the gingival pocket and on the border of the periodontal ligament (Figs. 16, 17).

The periodontal ligament and the splenial bony tissue of the alveolar process of the lower jaw bone are intact without inflammatory infiltration (Fig. 18).

After 2 hours (subgroup III - E), cornified layer was not observed, and the glittering layer remained in some segments. SSE was homogeneous; restoration of the cell structure and layers was beginning, with few vacuolar epithelial cells found in the granular and spinous layers. In the gingival pocket, fragments of coagulated inflammatory cells and sections of destroyed (vaporization) hair shafts were present. The edge of the gingival pocket is surrounded by loose fibrous tissue with adjacent (adhesive) fragments of coagulated inflammatory infiltration. In the gum LP, inflammatory infiltration of the tissue component was not observed; however, ectasia and plethora of blood capillaries, as well as of lymph capillaries with retention in the lumen of lymphocytes and eosinophilic leukocytes that did not move over the wall were seen (Figs. 19, 20).

After 3 hours (subgroup IV - E): SSE cornified layer was not present; a segmental narrow strip of the glittering layer was observed; SSE of the gum was homogeneous; restoration of the cell structure, and singular ridges in the tip of the free edge and few cells or cells in the form of short vacuole-type bundles (vaporization) in the granular and spinous layers were identified. In the gingival pocket, coagulated inflammatory infiltration fragments, minor spots of destroyed (coagulation and pre-coagulation changed) inflammatory cells and numerous sections of destroyed (vaporization) hair shafts were visualized. Epithelialization of the gingival pocket edge for $2 / 3$ its length was observed; it was surrounded by a narrow fibrous bundle in the bottom area (Figs. 21, 22).

No inflammatory infiltration of the tissue component was observed in the gum LP. Ectasia of blood and lymphatic vessels was identified, as well as retention of blood/lymph cells in their lumen that did not move beyond their wall. 


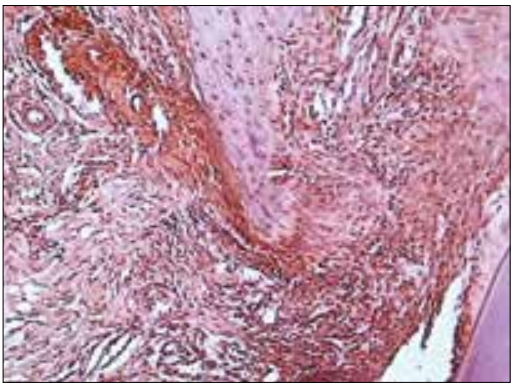

Fig. 13. The morphological changes of periodontium tissues in experimental animals 8 days after termination of the stress effect. SSE dystrophy and cytolysis, and slight oedema. Stained with haematoxylin and eosin. Magnification factor $200 \mathrm{X}$

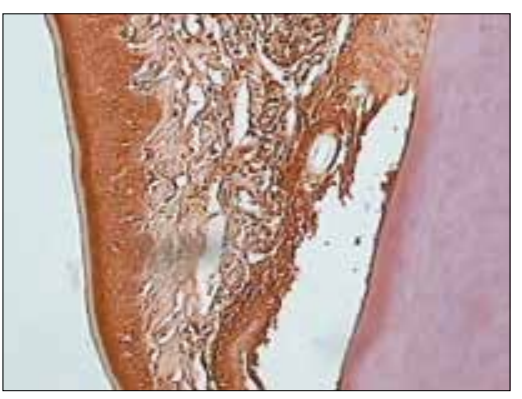

Fig. 16. The morphological changes of periodontium tissues in experimental animals 1 hour after magneto phototherapy. The SSE cornified layer not visualized. Stained with haematoxylin and eosin. Magnification factor $200 \mathrm{X}$
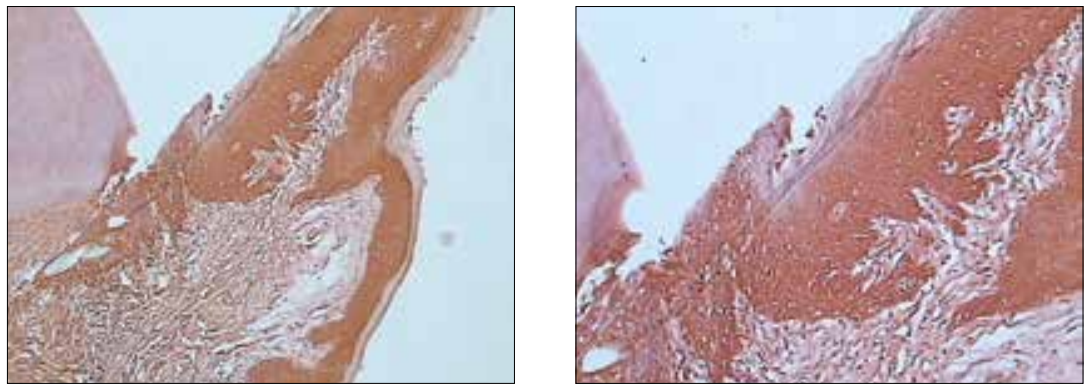

Figs. 14, 15. The morphological changes of periodontium tissues in experimental animals immediately after the impact of magneto phototherapy. Separation of the cornified and glittering layers. Cell vacuolization in the granular and spinous layers and pre-coagulation changes of SSE in the free edge and the fixed part. Stained with haematoxylin and eosin. Magnification factor $100-200 X$

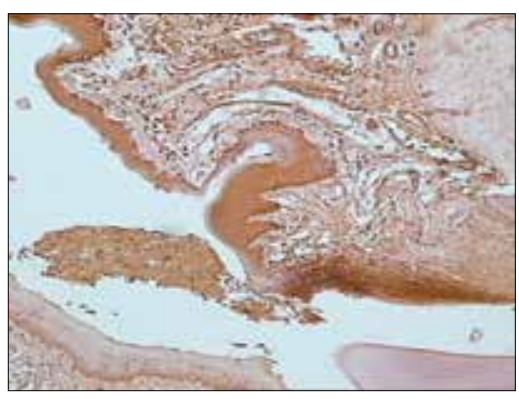

Fig. 17. The morphological changes of periodontium tissues in experimental animals 1 hour after magneto phototherapy. Total elimination of inflammatory lymph from the gingival pocket and formation of dense fibrous tissue along the edge of the gum SSE defect in the distal part and at the gingival pocket bottom. Stained with haematoxylin and eosin. Magnification factor 100X

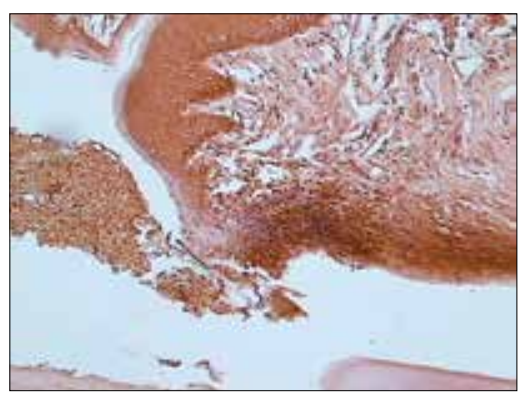

Fig. 18. The morphological changes of periodontium tissues in the experimental group 1 hour after magneto phototherapy. Absence of inflammatory infiltration in the periodontal ligament and the bone lamella. Stained with haematoxylin and eosin. Magnification factor 200X
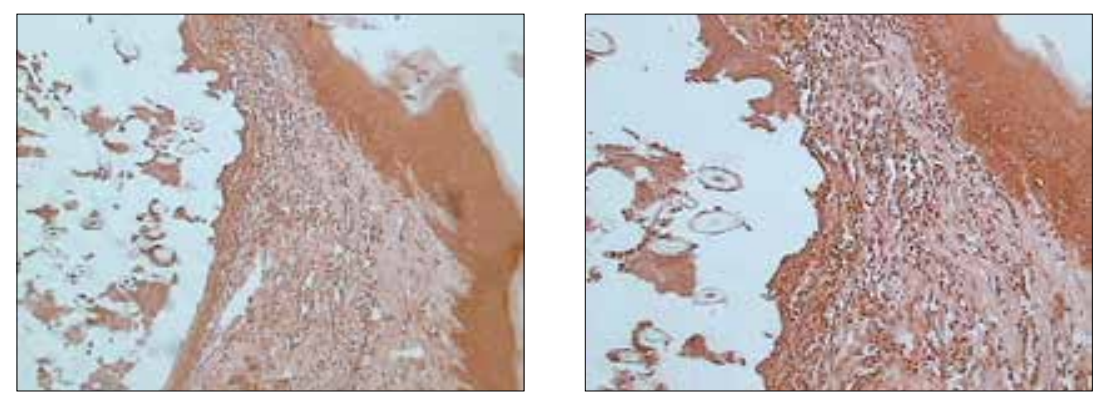

Figs. 19, 20. The morphological changes of periodontium tissues in experimental animals 2 hours after magneto phototherapy. No inflammatory infiltration of the tissue component; ectasia and plethora of blood capillaries. Stained with haematoxylin and eosin. Magnification factor 100-200X
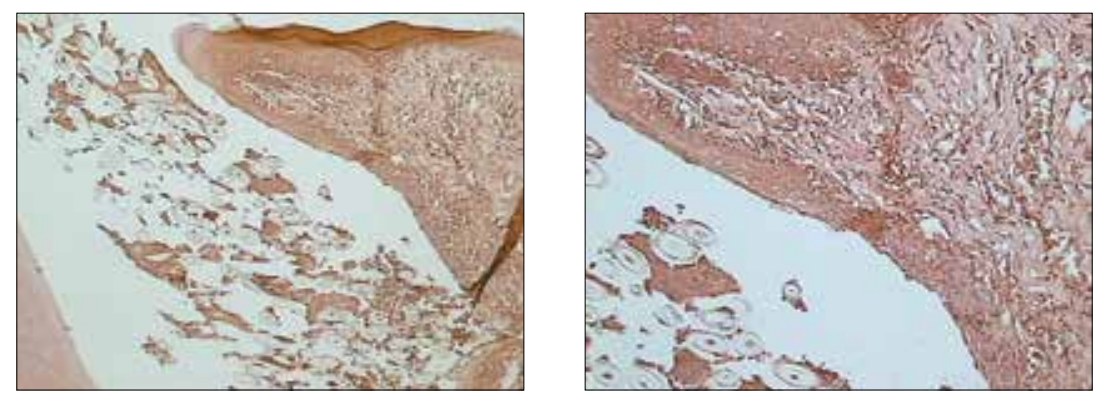

Figs. 21, 22. The morphological changes of periodontium tissues in experimental animals 3 hours after magneto phototherapy. Epithelialization of the gingival pocket edge over 2/3 of its length and its surrounding at the bottom area by a narrow fibrous tissue. Stained with haematoxylin and eosin. Magnification factor 100-200X 

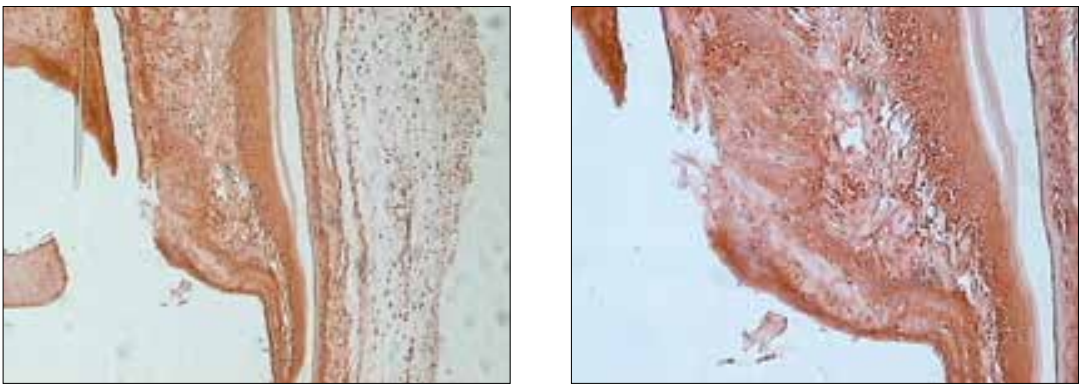

Figs. 23, 24. The morphological changes of periodontium tissues in experimental animals 1 day after magneto phototherapy. Ectasia of lymph capillaries and retention of few mononuclear cells in the lumen. Stained with haematoxylin and eosin. Magnification factor 100-200X

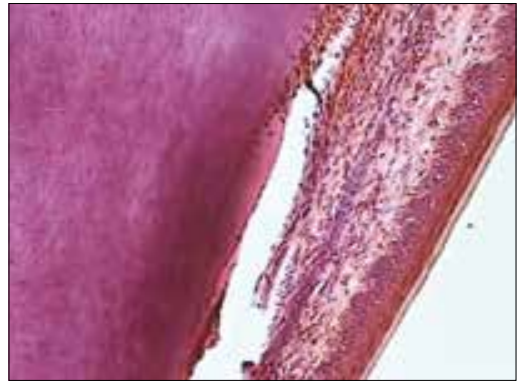

Fig. 25. The morphological changes of periodontium tissues in experimental animals 2 days after exposure to magneto phototherapy. No signs of inflammatory infiltration. Stained with haematoxylin and eosin. Magnification factor 200X

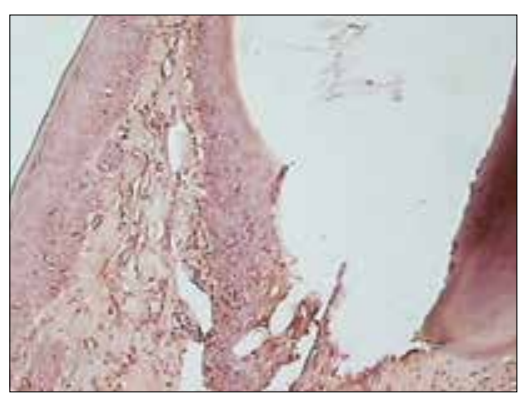

Fig. 28. The morphological changes of periodontium tissues in experimental animals 4 days after exposure to magneto phototherapy. The gingival pocket and its bottom are represented by a nonuniform SSE bundle. Stained with haematoxylin and eosin. Magnification factor 200X
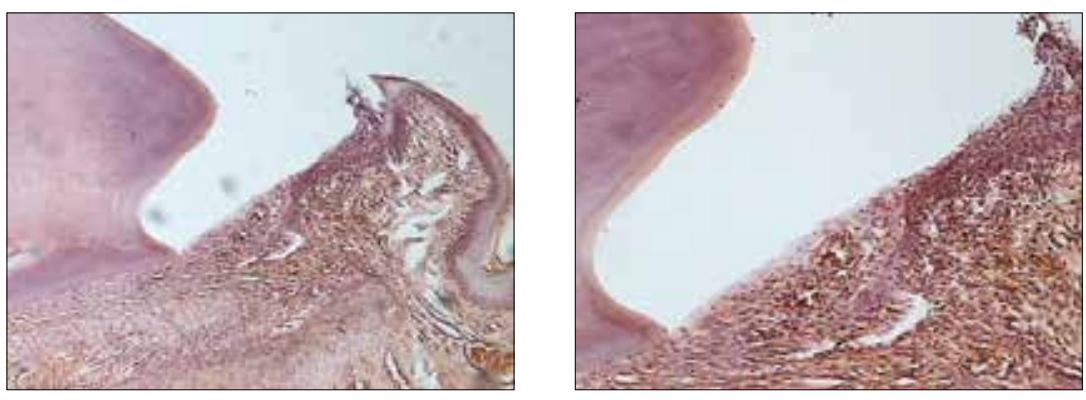

Figs. 29, 30. The morphological changes of periodontium tissues in experimental animals 5 days after magneto phototherapy. SSE cells in the free part of the gum match the control group; however, no cornified layer was observed. Stained with haematoxylin and eosin. Magnification factor 100-200X
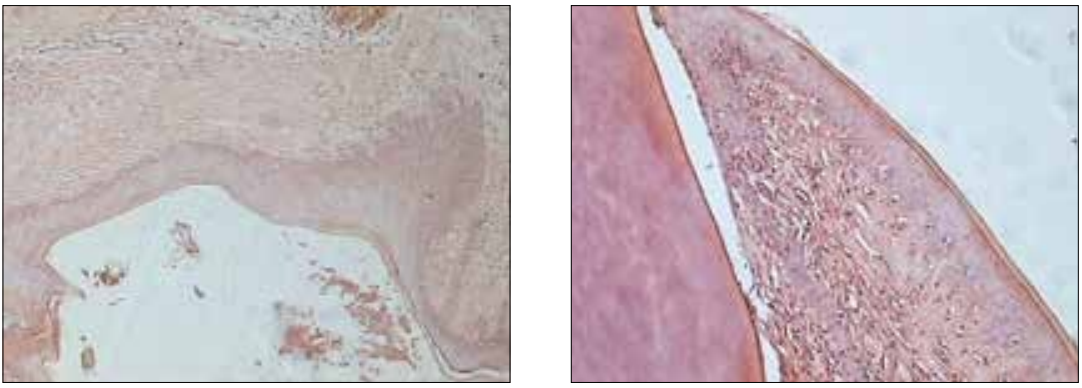

Figs. 31, 32. The morphological changes of periodontium tissues in experimental animals 8 days after magneto phototherapy. SSE of the free part of the gum contained, as in the control, glittering, granular, spinous and basal layers, without epithelial ridges. Stained with haematoxylin and eosin. Magnification factor 100-200X 
After one day (subgroup $V-E$ ), SSE of the external edge in the free part of the gum had uniform thickness and contained a glittering layer; cornified layer was not observed. Weak hyperplasia of the basal layer cells was identified in some places, without epithelial ridges. The gingival pocket was narrow without any content, and its bottom represented a narrow strip of small-cell LP with homogeneous thick and pale stained CFs. The internal edge of the free and separated part of the gum was surrounded by a narrow bundle of scattered and disordered epithelial cells. The LP represented homogeneous thickened and pale stained CFs. Ectasia of lymph capillaries was observed as well as retention of a few mononuclear cells in the lumen that do not move beyond their wall (Figs. 23, 24).

On day 2 (subgroup $V I-E$ ) after termination of magneto phototherapy, a uniform thin glittering epithelial layer was visualized, with no cornified layer not observed. SSE of the free edge of the gum had moderate thickness with clear cellular and layer differentiation; the granular layer was thick in some spots. The gingival pocket was without any content, its edge was epithelialized over its entire length, and epithelium was represented by a narrow bundle with disordered epithelial cells. The gum LP included compactly packed CFs, with no signs of inflammatory infiltration; retention of a few (1 or 2) mononuclear cells in the lumen of lymph capillaries that do not move beyond their wall was observed (Fig. 25).

On day 3 (subgroup VII $-E$ ), a uniform thin glittering layer was observed along the free edge and the gingival pocket, with no cornified layer. SSE of the free edge of the gum matched the control group. The epithelium of the gingival pocket edge was thickened over the entire SSE at the expense of the granular and spinous layers, as well as due to moderate or focal hyperplasia of the basal layer cells with single thin and expanded ridges, inter alia, in the gingival pocket bottom area. Sometimes, the small segment of the gingival pocket bottom (at the tooth enamel edge) was closed by dense fibrous tissue with encapsulated hair shaft segment. The gum LP represented thin CFs, predominantly compactly packed, without signs of inflammatory infiltration. Ectasia of blood capillaries was observed as well as spots or strips of mononuclear cells retention in the lumen of lymph capillaries that did not move beyond their wall (Figs. 26, 27).

On day 4 (subgroup VIII - E), a thin glittering epithelial layer was visualized at the edge of the free part of the gum and along the gingival pocket edge, with no a cornified layer. SSE of the free part of the gum with differentiated cells and layers; individual vacuolar cells were observed in the spinous layer. A nonuniform SSE layer (epithelialization of the gingival pocket edge) was found along the entire length of the gingival pocket edge (to the pocket bottom); in the distal; part, it was thickened in some places due to hyperplasia of the granular and spinous layer cells with disordered cell structures. The gingival pocket and its bottom were represented by a nonuniform SSE bundle and in some places (along the tooth enamel edge) by fibrous cell tissue with "internal" hair shaft segment and an elongated shallow cavity without lining or content (Fig. 28).

The gum LP included compactly packed CFs, without signs of inflammatory infiltration, with few small capillaries, single mononuclear cells in some of the lymph capillaries and cystic dilated lymphatic vessel in some spots.

On day 5 (subgroup IX $-E$ ), SSE of the free edge of the gum matched the control group, the difference lied in that no cornified layer was observed. The gingival pocket, as in the control group, was narrow without any content. Its edge represented a narrow SSE strip, with slightly expanded granular layer in some places, but without a glittering layer. The epithelial cells of the gingival pocket edge were disorderly packed. The area of fixing to the tooth bone included fibrous cell tissue. The gum LP was represented by CFs of different thickness. Uneven dilatation of sinusoidal lymph capillaries and diffused weak (mostly one cell) retention of mononuclear cells in the lymphatic vessels were observed; in some places in the form of a chain along the edge, with no signs of inflammatory infiltration, can be seen (Figs. 29, 30).

On day 8 after magneto phototherapy (subgroup $\mathrm{X}-\mathrm{E}$ ), SSE of the free edge of the gum contained, as in the control group, glittering, granular, spinous and basal layers were present, without epithelial ridges. The gingival pocket was narrow without any content. The gingival pocket edge was surrounded by a relatively narrow SSE strip, in some places with a relatively broad granular layer and a narrow layer of spinous and basal cells; without a glittering layer or epithelial ridges in some spots. The fixing area was represented by a narrow strip of dense fibrous tissue and a narrow strip of loose fibrous tissue (Figs. 31, 32).

The gum LP included densely packed CFs, chains of dilated sinusoidal lymph capillaries, small spots and strips of retention of a few mononuclear cells in the lymph capillaries without signs of inflammation. 


\section{CONCLUSION}

Specific microscopic changes of the gum and their trends, noticeably differing from the gum microscopic structure in rats of the control group and the experimental group, were found:

1. Coagulation and vaporization (partial or full) of inflammatory lymph from the gingival crevice/gingival pocket and inflammatory cells of the gum LP, pre-coagulation changes of the stratified squamous epithelium in the free and fixed parts of the gum were observed immediately after the exposure.

2. Dynamic changes in the gum microscopic structure were observed 1 hour after the exposure and included total elimination of inflammatory lymph of the gingival pocket and inflammatory cells of the gum LP, or remaining pre-coagulation changes; after 2 hours they included signs of beginning regeneration of the gingival pocket (delimitated by a narrow bundle of mature fibrous tissue); after 3 hours, restoration of the cell structure of the gum epithelium, partial epithelialization of the gingival pocket, which was more obvious after 1 day and almost full after 2 days.

3. Ectasia (and plethora) of the blood and lymph sinusoidal capillaries o the gum LP with mononuclear cells retention in the latter was observed after 3 hours, with a moderate growth of intensity during the subsequent observation periods; this sign remaining up to 8 days.

Thus, early elimination of inflammation (1 hour after termination of the impact) in all gum components and perifocal structures due to vaporization of inflammatory cells, activation of vessels (plethora and a noticeable increase in number) was found after the exposure to magneto phototherapy, while regeneration and complete epithelialization of the gingival pocket completed 2 days after termination of magneto phototherapy.

\section{References}

1. Denisova, Yu.L., Bazylev, N.B., Rubnikovich, S.P., Fomin, N.A., Laser speckle technology in stomatology. Diagnostics of stresses and strains of hard biotissues and orthodontic and orthopaedic structures. J. of Engineering Physics and Thermophysics, Germany, 2013, vol. 86, no. 4, pp. 940-951.

2. Rubnikovich, S.P., Bazylev, N.B., Fomin, N.A., New possibilities of investigating blood flow in soft tissues of the mouth. J. of Engineering Physics and Thermophysics, Germany, 2008, vol. 81, no. 3, pp. 533-543,

3. Bazylev, N.B., Rubnikovich, S.P. Investigation of the stressed-strained state of cermet dentures using digital laser speckle-photographic analysis.

J. of Engineering Physics and Thermophysics, Germany, 2009, vol. 82, no. 4, pp. 789-793,

4. Rubnikovich, S.P. Use of digital dynamic speckle anemometry for diagnosis of the surface blood flow in the mouth cavity tissue.

Stomatologicheskii Zhurnal - Stomatological Journal 2007, no. 3, p. 26.

5. Akhmedov, G.D., Hemodynamic and regenerative efficacy of magnetic therapy in the postoperative period of dental implantation. Moscow,

Institut stomatologii. - Institute of Stomatology, 2011, no. 3, pp. 62-64,.

6. Denisov, L.A., Dedova L.N. Vacuum d'arsonvalization in the treatment of periodontitis. Voprosy Kurortologii, Fizioterapii i Lechebnoi Fizicheskoi Kultury, 1982, no. 2, p. 26

7. Dedova, L.N., Denisov, L.A. The treatment of apical periodontitis by using combined exposure to focal measured vacuum and local d'Arsonval treatment. Stomatologiya - Stomatology 1991, no. 1, p. 26.

8. Dedova, L.N. Morphological characterization of the experimental periodontium. Stomatologicheskii Zhurnal - Stomatological Journal 2005, vol. 3 , p. 12 .

9. Voichenko, N.V. Comparison of magneto and magneto phototherapy in experimental arthritis. Minsk, Novosti Mediko-Biologicheskikh

Nauk - News of biomedical sciences, 2012, no. 2, pp. 129-136.

10. Ilyukevich, G.V., Konkov, S.V., Pletnev, S.V. Method of magnetic photo effect in intensive care of patients with burn disease. Minsk, UMP, BelMAPO, 2013, pp. 4-6.

11. Rubnikovich, S.P., Denisova Yu.L. Complex treatment of patients with periodontal diseases in combination with dentoalveolar anomalies and deformations. Minsk, Stomatologist, 2013, no. 4 (11), pp. 13-27.

12. Rubnikovich, S.P., Lahoyski A.V. Complex assessment of the state of microcirculation of periodontal tissues with partial secondary adentia

Minsk, Medical Journal, 2013, no. 1, pp. 108-110

13. Rubnikovich, S.P., Denisova Yu.L., Bazilev N.B., Fomin N.A. Panoramic diagnosis of stresses and deformations of solid biotissues and orthopedic structures using speckle technologies. Minsk, Reports of NAS of Belarus, 2013. No. 4, pp. 37-41.

14. Rubnikovich, S.P., Denisova Yu.L., Fomin N.A. New laser methods of diagnostics and therapy in stomatology. Minsk, LAP-Lambert academic publishing, pp. $348 \mathrm{c}$.

15. Denisova Yu.L., Rubnikovich, S.P., Denisov L.A. A new method for studying the periodontal capillary pressure in dentistry. Innovative technologies in medicine, Minsk, 2013, no. 1, pp. 41-45.

16. Rubnikovich S.P., Timchyk Y.I., Baradina I.N., Denisova Yu.L. Complex treatment of periodontal disease. Minsk, Teaching aid, 2016,34 pp.

17. Rubnikovich S.P., Kostecky Y.A., Baradina I.N., Denisova Yu.L. Therapeutic preparation of a dental patient for orthopedic treatment. Minsk, Teaching aid, 2014, 36 pp.

18. Denisova Yu.L. Prognosis of periodontal disease in patients with dental-jaw deformities. Minsk, Stomatologist, 2012 , no. 4, pp. $21-25$.

19. Rubnikovich S.P., Baradina I.N. Modern technologies in the treatment of patients with dysfunction of temporomandibular joints. Minsk, Innovative technologies in medicine, 2014, no. 2, pp. 111-118.

20. Rubnikovich, S.P., Denisova Yu.L., Baradina I.N., Khomich I. S., Maizet A.I. Laser-optical diagnostics in stomatology. Minsk, Teaching aid, 2014, 24 pp.

21. Rubnikovich, S.P., Vladimirskaya, R.E., Shved, I.A., and Veyalkina, N.N. Simulation of experimental periodontitis in animals. Minsk Medicinskij zhurnal. - Medical Journal, 2011, no. 1 (35), pp. 97-101.

22. Denisova, Yu.L., Vladimirskaya, T.E. Experimental justification of the use of vacuum UVR therapy in comprehensive treatment of patients with periodontitis combined with c dentition abnormalities and deformations. Minsk, Medicinskij zhurnal. - Medical Journal, 2012, no. 3, pp. 70-74.

23. Denisova, Yu.L. Vladimirskaya, T.E. Experimental justification of vacuum laser therapy in comprehensive treatment of patients with periodontitis combined with c dentition abnormalities and deformations. Minsk, Voennaja medicina. - Military medicine, 2013 , no. 1, pp. $103-107$. 24. Anaesthesia of Experimental Animals: Methodological Recommendations. Moscow, 1985, $54 \mathrm{p}$.

25. Denisov, S.D., Morozkina, T.S., Requirements to a scientific experiment on animals. Zdravookhranenie-Health care, 2001, no. 4, p. 40. 